\title{
Effect of Quercetin on the Endocrine Pancreas of the Experimentally Induced Diabetes in Male Albino Rats: A Histological and Immunohistochemical Study
}

\author{
Rehab Ahmed Rifaai*, Nashwa Fathy El-Tahawy, Entesar Ali Saber and Randa Ahmed
}

Department of Histology, Faculty of Medicine, El-Minia University, Egypt

\begin{abstract}
Background: Insulin dependent diabetes mellitus is a chronic metabolic disease. Many drugs used in its treatment which have a number of serious adverse effects. Natural agent as quercetin (QCT) has been suggested in the alternative medicine for treatment of diabetes mellitus.
\end{abstract}

Aim of the work: To evaluate the effect of QCT on the histological changes which occur in the islet of Langerhans of the streptozotocin (STZ)-induced diabetic rats and the possible mechanisms through which QCT produces its protective effect.

Materials and methods: Fourty five male albino rats were divided into 3 groups: Group I, control group; 15 rats received single intraperitoneal injection of citrate buffer saline. Group II, diabetic group; 15 rats received single intraperitoneal injection of STZ. Group III; QCT-treated group, 15 rats received daily intraperitoneal injections of QCT for 30 days prior to, and for 30 days after the single injection of STZ. Blood samples were taken for monitoring blood glucose levels. Pancreas was taken out and processed for light microscopic, immunocytochemical and morphometrical studies.

Results: Blood glucose levels showed a significant increase in group II compared to the control, while a significant decrease was observed in groups III compared to group II (all p<0.05). In the hematoxylin-eosin stained sections, STZ administration caused marked degeneration of islet Beta cells with inflammatory cells infiltration. Using QCT; in group III, reversed most of the pancreatic morphological changes, and interestingly some islets noticed with connections to some pancreatic ducts. In chrome alum heamatoxylin stained sections, STZ administration caused a significant decrease in the number of bluish stained $\beta$ cells compared to controls. While group III showed a significant increase in $\beta$ cells number compared to group II (all $p<0.05$ ). Sections of animals injected with charcoal, showed many charcoa labeled macrophages in group II compared to group III, and controls. There was increased iNOS and caspase 3 immunoreactivity in islets cells of group II than in controls, and was decreased in group III.

Conclusion: This study provides evidence that quercetin could exert a protective effect against $\beta$ cell damage by its anti-inflammatory, anti-apoptotic, and antioxidant effects; and aids regeneration of $\beta$ cells which might through stimulation of the ductal stem cells. However, further experimental studies are still needed for more details on quercetin as an adjuvant drug in management of diabetes mellitus.

\section{Introduction}

Diabetes mellitus (DM) is a chronic metabolic disease characterized by hyperglycemia and disturbances in carbohydrate, fat and protein metabolism. It is associated with an absolute or relative deficiency in the secretion of insulin (Diabetes Mellitus 1, DM1) or with insulin resistance (Diabetes Mellitus 2, DM2) [1]. Type 1 DM results from autoimmune destruction of the pancreatic $\beta$ cells that lead to severe deficiency or relative lack of insulin, the key pancreatic hormone necessary for glucose homeostasis [2].

The management of hyperglycemia with low side effects is still a challenge for the medical system and many drugs have several serious adverse effects [3]. Another problem faced is the cost of the treatment, which is often prohibitively high in developing countries [4].

Streptozotocin (STZ) is an antibiotic produced by Streptomyces achromogenes. It has been widely used for inducing experimental diabetes mellitus in a variety of animals, it stimulates the naturally occurring metabolic disorder DM by causing degeneration of pancreatic $\beta$ cells $[5,6]$. The selective $\beta$ cell toxicity of STZ is related to the glucose moiety in its chemical structure, which enables STZ to enter the cell via the low affinity glucose transporter Glut2 in the plasma membrane [7].

Nitric oxide synthase (NOS) is present in pancreatic $\beta$ cells, and may be involved in the release of insulin under normal physiological conditions [8]. However, other findings suggest that iNOS isoform may play a role in the destruction of $\beta$ cells during the development of DM2 [9].

For many reasons in recent years the popularity of alternative medicine has increased, this has led to increasing demands for herbal products with anti diabetic activity and less side effects [10]. Flavonoids occur commonly, and are widespread, in the plant kingdom. Querectin (QCT) is one of the most widely distributed flavonoids, present in foods, including vegetables, especially onions, fruits, tea, and many

*Corresponding author: Rehab Ahmed Rifaai, Department of Histology Faculty of Medicine, El-Minia University, Egypt, Tel: 01003358376; E-mail: rehabrifaai@yahoo.com

Received March 03, 2012; Accepted March 24, 2012; Published March 29, 2012

Citation: Rifaai RA, El-Tahawy NF, Saber EA, Ahmed R (2012) Effect of Quercetin on the Endocrine Pancreas of the Experimentally Induced Diabetes in Male Albino Rats: A Histological and Immunohistochemical Study. J Diabetes Metab 3:182. doi:10.4172/2155-6156.1000182

Copyright: @ 2012 Rifaai RA, et al. This is an open-access article distributed unde the terms of the Creative Commons Attribution License, which permits unrestricted use, distribution, and reproduction in any medium, provided the original author and source are credited. 
Citation: Rifaai RA, El-Tahawy NF, Saber EA, Ahmed R (2012) Effect of Quercetin on the Endocrine Pancreas of the Experimentally Induced Diabetes in Male Albino Rats: A Histological and Immunohistochemical Study. J Diabetes Metab 3:182. doi:10.4172/2155-6156.1000182

other dietary sources [11]. Flavonoids are frequently exhibited antioxidant activity. An increased consumption of antioxidants in the diet of individuals is strongly recommended [12].

The aim of this work is to evaluate the effect of QCT on the histological changes which occur in the islet of Langerhans of the STZinduced diabetic rats and the possible mechanisms through which QCT produces its protective effect.

\section{Material and Methods}

\section{Animals used}

This study was conducted in the Histology department, faculty of Medicine of El-Minia University. Forty five males albino rats at the age 8-10 weeks, weighting 200-250 grams were used. Animals were housed in a clean plastic cage and were given food and water ad libitum.

\section{Reagents}

1-Streptozotocin (STZ) vial containing $1 \mathrm{~g} \mathrm{STZ}$ and $220 \mathrm{mg}$ citric acid was obtained from Sigma Aldrich, which was freshly dissolved in $0.1 \mathrm{~mol} / 1$ citrate buffer, $\mathrm{pH} 6$.

2-Querectin (QCT) (3,5,7,3',4'-pentahydroxyflavone) was obtained from Sigma Aldrich, dissolved in $0.5 \mathrm{ml}$ of $60 \%$ ethanol just before injection according to manufacturer's instructions.

\section{Experimental design}

Animals were randomly divided into three groups as following:

The control group (group I): It consists of 15 rats which received a single intra peritoneal injection of citrate buffer saline.

The Diabetic group (group II): It consists of 15 rats in which diabetes was induced by a single intra peritoneal injection of STZ in a dose of $75 \mathrm{mg} / \mathrm{kg}$ body weight [13].

The QCT-treated group (group III): It consists of 15 rats. Rats were received a daily intra peritoneal injection of QCT $(25 \mathrm{mg} / \mathrm{kg}$ body weight/day). This treatment was started 30 days prior to induction of diabetes. Induction of diabetes was done by injection of a single dose of STZ, and then QCT was continued for another 30 days.

In this study, the day of intraperitoneal injection of STZ was determinated as (day 0 ) and every other day thereafter. Blood samples were taken after overnight food deprivation. Samples were taken from tail veins for monitoring blood glucose levels at $48 \mathrm{~h}$ and on the day 30 after injection of STZ.

Four rats from the different groups were slowly intravenously injected with $0.3 \mathrm{ml}$ aqueous buffered solution formed of suspension of carbon particles $(0.5 \mathrm{ml})$ in normal saline $(100 \mathrm{ml})$, two hours before the sacrifice. This was to determine the phagocytic uptake of the carbon particles by the macrophages [14].

At day 30 for all groups rats were sacrificed by decapitation under light halothane anesthesia, specimen were removed and the splenic portions (tail) of the pancreas were taken, then dissected and rapidly fixed in $10 \%$ formal saline for 48 hours, then specimens were processed for morphological and morphometric studies.

\section{For biochemical study}

The glucose level was confirmed by the use of One Touch Glucometer and compatible blood glucose test strips. STZ treated rats with blood glucose level $\geq 18 \mathrm{mmol} /$ litre were considered to be diabetic and used in this study [15].

\section{For light microscopy}

The specimens were fixed in $10 \%$ neutral-buffered formalin, dehydrated in a graded ethanol series, cleared in xylene and embedded in paraffin wax. Some sections $(5 \mu \mathrm{m}$ thick) were stained with haematoxylin and eosin (H\&E). For detection of alpha and beta cells, other sections were stained with Gomori's chrome alum hematoxylinphloxine stain [16].

\section{For immunohistochemical study}

Immunocytochemical staining was performed using polyclonal rabbit antibodies (anti-cleaved caspase 3 and iNOS). Immunohistochemistry for active caspase and iNOS was performed on formalin-fixed, paraffin-embedded tissue. Sections were deparaffinized, hydrated then washed in $0.1 \mathrm{M}$ phosphate buffer saline (PBS). Endogenous peroxidases were quenched by treatment with $\mathrm{H}_{2} \mathrm{O}_{2}$ in methanol (Peroxidase blocking solution) followed by washing in tris buffer saline (TBS). Non-specific binding of IgG was blocked using normal goat serum, diluted $1: 50$ in $0.1 \%$ bovine serum albumin with TBS for 30 minutes. The sections were incubated with the diluted primary antibodies for cleaved caspase 3 (1:500) and iNOS (ready to use) overnight at room temperature. Sections then were washed 3 times each for 5 minutes in buffer and incubated for further 30 minutes with biotinylated goat anti-rabbit secondary antibodies diluted 1:1000, followed by washing. Following further 30 minutes incubation with Vectastain ABC kits (Avidin, Biotinylated horse radish peroxidase Complex) and washing for 10 minutes, the substrate, diaminobenzidine tetra hydrochloride (DAB) in distilled water was added for 5-10 min. The enzyme reaction was developed as described previously. The slides were lightly counterstained by hematoxylin to gain a good morphological identification of cells, and dehydrated by passing through ascending concentrations of alcohol then cleared by xylene. Cover slip using permanent mounting media is put at last. This substrate gives brown color at the immunoreactive sites [17].

Photography: Olympus light microscopy was used. Slides were photographed using Olympus digital camera. Images were processed using Adobe Photoshop.

Morphometric analysis: The procedures utilized a hardware consisting of a high-resolution color digital camera mounted on an Olympus BX51 microscope and connected to a computer. Four sections were examined from each animal in the different groups.

\section{Quantitative data were collected for 4 parameters}

The number of islets per square millimeter of each section: The islets of the pancreas were counted in H\&E slides in random microscopic areas under 10 high power fields. The number of islets was assessed by counting all islets per one square millimeter of different non overlapped fields for the same slide of each animal.

The number of $\beta$ cells in the islet: The $\beta$ cells of the pancreas were counted in chrome alum hematoxylin slides under 40 high power fields. The number of $\beta$ cells was assessed by counting all nuclei of the blue stained cells inside one islet in the field. Approximately 4 islets were included on each section. In each animal 3 sections were counted and a total number of 60 islets of each group were counted.

Counting the number of $\beta$ cells, and the total number of cells in the pancreatic islets: Chrome alum hematoxylin stained sections were used to assess the number of $\beta$ cells and the total number of cells in the pancreatic islets in 40 high power fields. The number of $\beta$ cells was assessed by counting all nuclei of the blue stained cells inside one islet 
Citation: Rifaai RA, El-Tahawy NF, Saber EA, Ahmed R (2012) Effect of Quercetin on the Endocrine Pancreas of the Experimentally Induced Diabetes in Male Albino Rats: A Histological and Immunohistochemical Study. J Diabetes Metab 3:182. doi:10.4172/2155-6156.1000182

Page 3 of 11

in the field. The total number of cells in the same islet was calculated by counting the all nuclei in the islet. Approximately 4 islets were included on each section. Three sections were used for each animal in the group, and a total number of 60 islets for each group were counted.

The same islets in the same fields were used for counting both $\beta$ cells and the total number of cells. The ratio between number of beta cells of the islet to the total number of cells in the same islet was calculated in each experimental group. The Percent of $\beta$ cells was calculated by dividing the number of B cells / the total number of cells in each islet $\mathrm{x} 100$.

\section{Data handling and statistics}

The mean number $(\mathrm{MN})$ and standard deviation (SD) were determined for parameter in each group. The significance of differences observed in these groups was pooled and assessed by the student $t$-test

\section{Results}

\section{Biochemical study}

Blood glucose levels of the control group showed normal levels with a mean of $4.2 \pm 0.7 \mathrm{mmol} / \mathrm{L}$ throughout the study. In the diabetic group, there was a significant increase in blood glucose levels $48 \mathrm{~h}$ after STZ injections, and get its highest levels by 30 days after STZ injections (all $\mathrm{p}=0.000$ ). While in the QCT-treated group, there was a significant decrease in blood glucose levels $48 \mathrm{~h}$ and 30 days after STZ injections ( $\mathrm{p}=$ 0.000), compared to the diabetic group. On the other hand, the QCTtreated group had relatively similar blood glucose levels compared to controls as there was no significant difference noted either at $48 \mathrm{~h}$ or 30 days after STZ injections ( $\mathrm{p}=0.011, \mathrm{p}=0.006$ respectively) (Table 1 ).

\section{Histological study}

Histological study of pancreas using hematoxylin and eosin: The control group (group I) showed a normal lobular architecture of the pancreas. The pancreas had abundant islet of langerhans interspersed among the pancreatic exocrine acini. The islets appeared lightly stained than the surrounding acinar cells, with intact Interlobular connective tissue and interlobular duct (Figure1). Each islet consisted of lightly stained polygonal cells arranged in cords separated by a network of blood capillaries. The acinar cells were characterized by its basal basophilia and apical acidophilia (Figures 2,3).

The pancreatic sections of the diabetic group (group II) showed marked morphological changes. The border between the endocrine and exocrine region became indistinct. Inflammatory cells infiltration through the connective tissue septa and around to the periphery of the islets (Figure 4). The inflammatory cells were also seen surrounding ducts, in between the acini and inside the lumen of blood vessels. Most of these cells were neutrophils, eosinophils and macrophages (Figure $5,6)$. Blood vessels were seen congested and dilated (Figure 6). Some

\begin{tabular}{|l|l|l|l|l|}
\hline & \multicolumn{3}{|c|}{ Blood glucose levels (mmol/L) } \\
\cline { 2 - 5 } & after 48 hours & after 30 days \\
\cline { 2 - 5 } & Mean \pm sd & p-value & Mean \pm sd & p-value \\
\hline Control group & $4.2 \pm 0.7$ & & $4.2 \pm 0.5$ & \\
\hline Diabetic group & $18.2 \pm 0.3$ & $0.000^{c}$ & $21.3 \pm 0.4$ & $0.000^{c}$ \\
\hline QCT- treated group & $4.7 \pm 0.1$ & $0.000^{\mathrm{d}}$ & $4.6 \pm 0.1$ & $\begin{array}{l}0.000^{\mathrm{d}} \\
0.006^{\mathrm{c}}\end{array}$ \\
\hline
\end{tabular}

$p<0.05$ is significant, ${ }^{c}$ versus control group, ${ }^{d} Q C T$-treated group versus diabetic group. Values are expressed as means ( \pm SEM) of 10 rat

Table 1: Comparison of blood glucose levels ( $\mathrm{mmol} / \mathrm{L}$ ) in the studied groups.

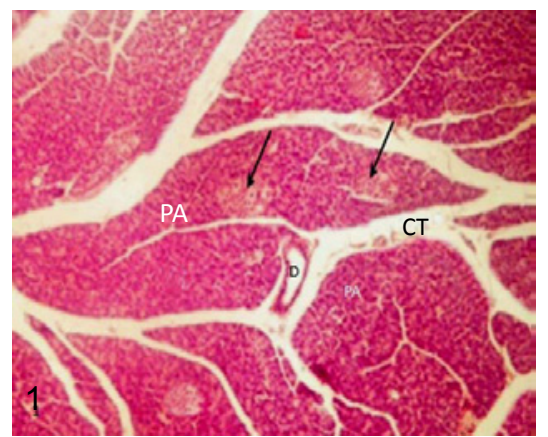

Figure 1: A Photomicrograph of rat pancreatic tissue of the control group showing normal lobular architecture. Islets of Langerhans (black arrows) seen surrounded by the pancreatic acini (PA). Notice the Interlobular connective tissue (CT) and the interlobular duct (D). (Hx\&E x100).

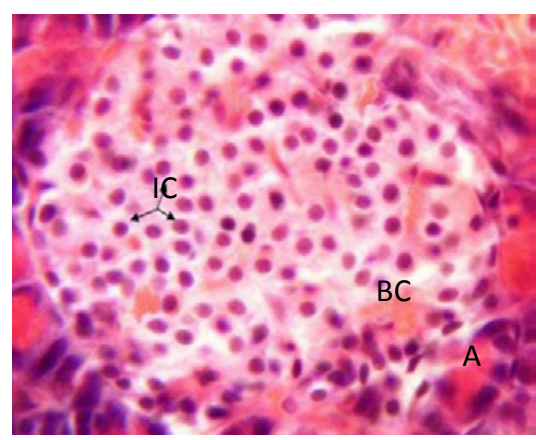

Figure 2: A photomicrograph of rat pancreatic tissue of the control group showing Islet's cells (IC) forming cords separated by a network of blood capillaries $(B C)$. Notice the pancreatic acini with its basal basophilia and apical acidophilia (A). (Hx\&E x400).

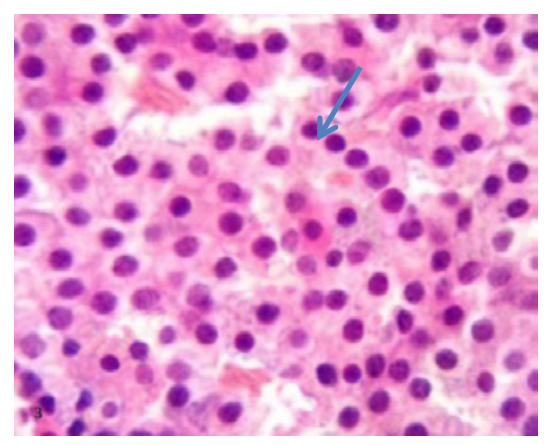

Figure 3: A photomicrograph of rat pancreatic tissue of the control group showing the lightly stained polygonal Islet's cells arranged in cords (blue arrow). (Hx\&E x1000).

islets were completely destroyed leaving empty spaces (Figure 7). The islet's cells showed different morphology. Some cells appeared with nuclear pyknosis and nuclear fragmentation. The degenerated cells surrounded by empty spaces which filled with amyloid-like material (Figure 8). The cellular residues were engulfed by the phagocytic cells leaving empty spaces (Figure 9).

In group III, QCT administration showed improvement in the previous morphological changes in most of the rats, the border between exocrine and endocrine portions became distinct (Figure 10). Many islets showed with an increase in the cellular density along with a 
Citation: Rifaai RA, El-Tahawy NF, Saber EA, Ahmed R (2012) Effect of Quercetin on the Endocrine Pancreas of the Experimentally Induced Diabetes in Male Albino Rats: A Histological and Immunohistochemical Study. J Diabetes Metab 3:182. doi:10.4172/2155-6156.1000182

reduction in the inflammatory cells infiltration inside the islet (Figures 10,11,12). Some ducts were noticed near islets with some cellular connection (Figure 13).

Histological study of the pancreas using Gomori's chrome alum hematoxylin-phloxine: The pancreatic islets of the control group showed that most of the cells were $\beta$-cells which stained deep blue filled the interior of the islet, while $\alpha$-cells appeared pink to red and arranged in clusters scattered either between $\beta$-cells or at the periphery of the islets (Figure14).

The Diabetic group (group II), the islets showed degenerative

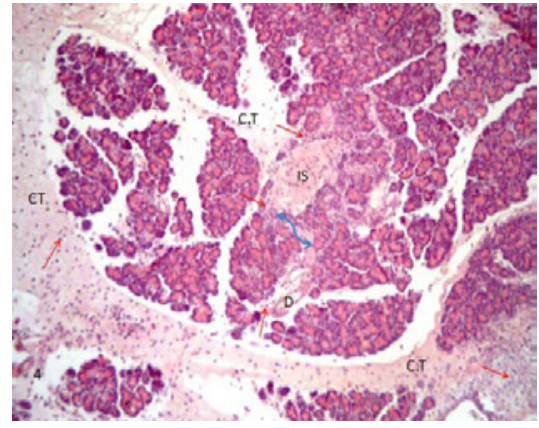

Figure 4: A photomicrograph of rat pancreatic tissue of the diabetic group showing the indistinct boundary between the endocrine and exocrine part (blue arrow). Notice inflammatory cells (red arrows) infiltrating through connective tissue septae (CT), islet area (IS) and around the duct (D). (Hx\&E x100).

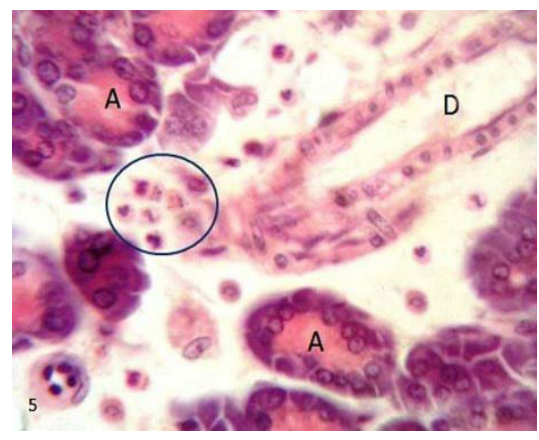

Figure 5: A photomicrograph of rat pancreatic tissue of the diabetic group showing inflammatory cells (blue circle) surrounding duct (D) and between acini $(A)$. (Hx\&E X400).

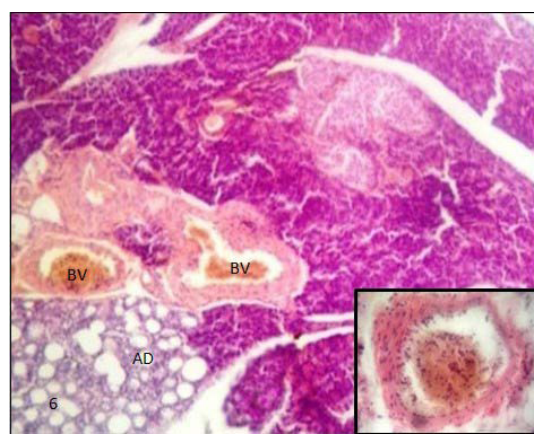

Figure 6: A photomicrograph of rat pancreatic tissue of the diabetic group showing some congested and dilated blood vessels (BV) with inflammatory cells infiltration (inset). (Hx\&E X100).

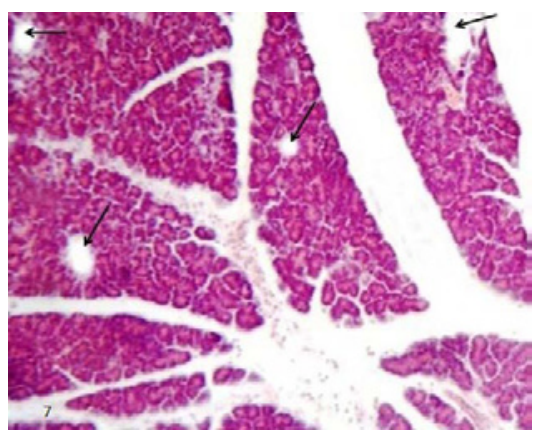

Figure 7: A photomicrograph of rat pancreatic tissue of the diabetic group showing completely destroyed islets leaving empty spaces (black arrows). (Hx\&E X100).

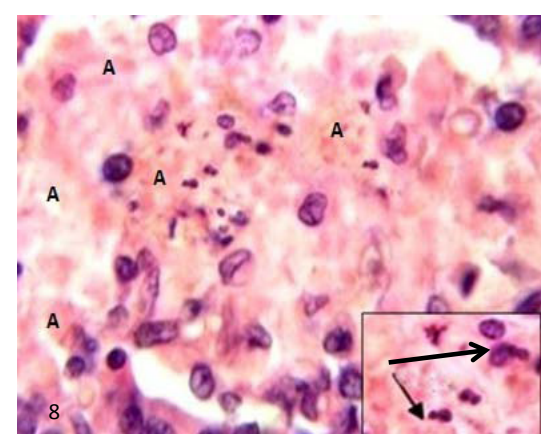

Figure 8: A photomicrograph of rat pancreatic tissue of the diabetic group showing degenerated islet's cells with nuclear pyknosis and nuclear fragmentation (Inset). Notice the empty spaces leaved after cell degeneration filled with amyloid-like material (A). (Hx\&E x1000).

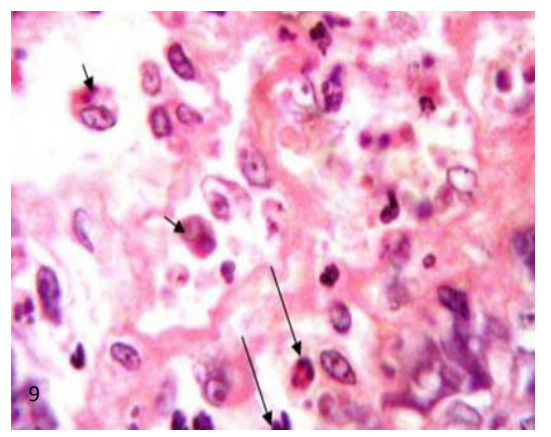

Figure 9: A photomicrograph of rat pancreatic tissue of the diabetic group showing the inflammatory cells infiltration inside the islet (long arrows). Noticed cellular residues within the cytoplasm of phagocytic cells (short arrows). The phagocytic cells are surrounded by empty spaces. (HX\&E X1000).

changes, especially at the center with decrease in the density of bluish stained $\beta$ cells. The remaining cells showed nuclear shrinkage and pyknosis. Pink to red stained alpha cells were still present at the periphery of islet and in between $\beta$ cells (Figure 15).

Group III showed improvement of islet morphology which approached the corresponding healthy pancreatic sections. There was also a relative increase in the $\beta$-cell mass (Figure 16).

Histological study of pancreatic macrophages using charcoal: Macrophages were monitored by charcoal injection (phagocytes 
Citation: Rifaai RA, El-Tahawy NF, Saber EA, Ahmed R (2012) Effect of Quercetin on the Endocrine Pancreas of the Experimentally Induced Diabetes in Male Albino Rats: A Histological and Immunohistochemical Study. J Diabetes Metab 3:182. doi:10.4172/2155-6156.1000182

Page 5 of 11

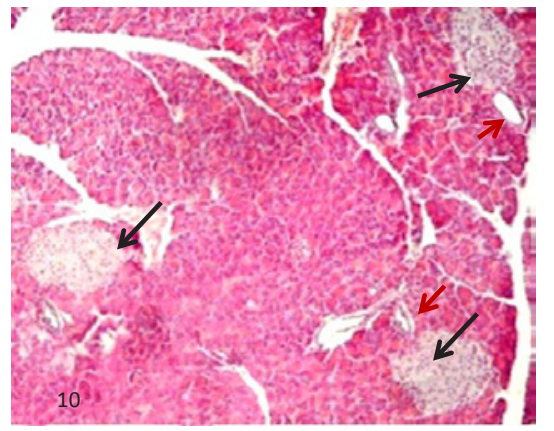

Figure 10: A Photomicrograph of rat pancreatic tissue of the quercetin treated group showing many islets with distinct border from surrounding exocrine part (black arrows). Notice presence of ducts near islets (red arrows). (Hx\&E x100).

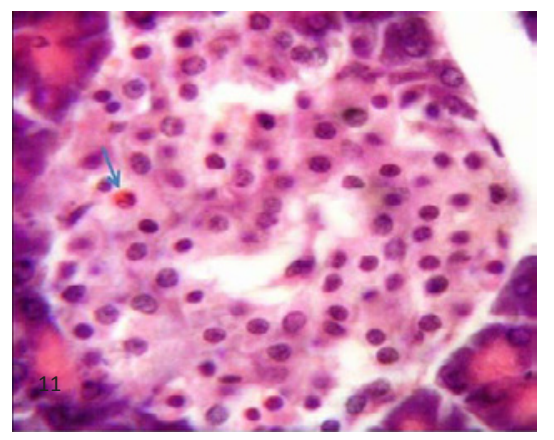

Figure 11: A Photomicrograph of rat pancreatic tissue of the quercetin treated group showing increase islet cell density. Notice reduction in the inflammatory cells infilteration (blue arrow indicates an eosinophil). (Hx\&E x400).

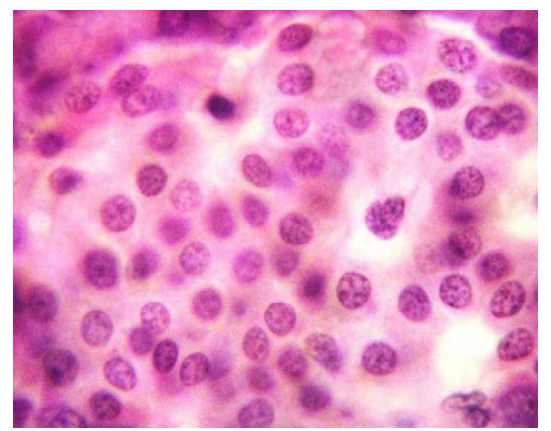

Figure 12: A Photomicrograph of rat pancreatic tissue of the quercetin treated group showing islet cells resemble normal. (Hx\&E X1000).

consider carbon particles of charcoal as a foreign body and uptake them so their cytoplasm displayed yellowish - brown granules).

In the control group (group I), the islet having charcoal injected blood vessels in between the islet's cells and in between acini with no labeled macrophage seen in the islet (Figure 17).

The Diabetic group (group II), the macrophages in the sections of this group appeared widely distributed when compared to the control group. They were more frequently increased in the islet's region. The labeled cells were large with irregular outline. Their cytoplasm displayed yellowish brown charcoal granules (Figure 18).
The QCT-treated group (group III), the labeled cells were markedly decreased all over the pancreatic sections, especially in the islet region compared to the previous group (Figure19).

\section{Immunohistochemical study}

Immunohistochemical study of the rat pancreatic tissues using iNOS: Sections of the control group displayed negative iNOS immunoreactivity in the islet cells, the acini and in the endothelium of the blood vessels (Figure 20).

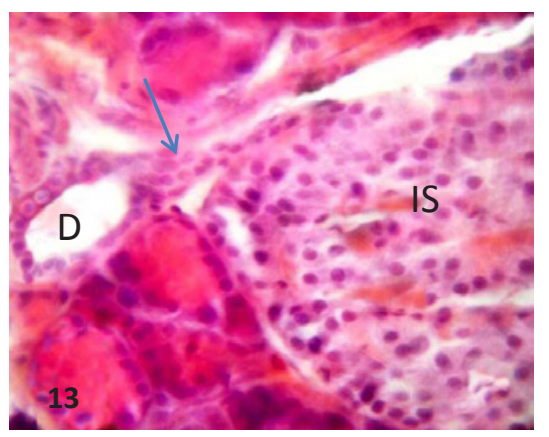

Figure 13: A photomicrograph of rat pancreatic tissue of the quercetin treated group showing connection between the duct (D) and islet cells (IS) (blue arrow). (Hx\&E x400).

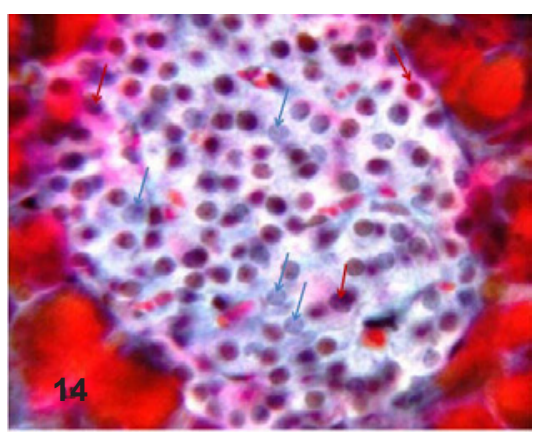

Figure 14: A Photomicrograph of rat pancreatic tissue of the control group showing $(\beta)$ cells stained deep blue filling the interior of the islet(blue arrows) ,while $\alpha$-cells stained pink to red scattered mainly at the periphery of the islets and between ( $\beta$ ) cells(red arrows). (chrome alum Hx.X 400).

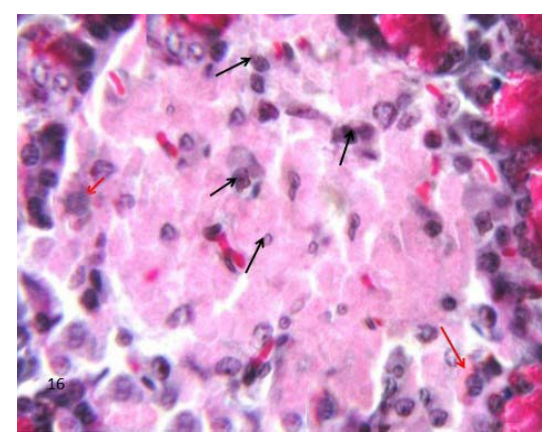

Figure 15: A Photomicrograph of rat pancreatic tissue of the diabetic group showing decreased cellular density, the degenerated cells are showed with nuclear shrinkage and pyknosis (black arrows) mostly in the center of the islet. Notice pink stained alpha cells at the periphery of islet (red arrows). (chrome alum Hx. X400). 
Citation: Rifaai RA, El-Tahawy NF, Saber EA, Ahmed R (2012) Effect of Quercetin on the Endocrine Pancreas of the Experimentally Induced Diabetes in Male Albino Rats: A Histological and Immunohistochemical Study. J Diabetes Metab 3:182. doi:10.4172/2155-6156.1000182

Page 6 of 11

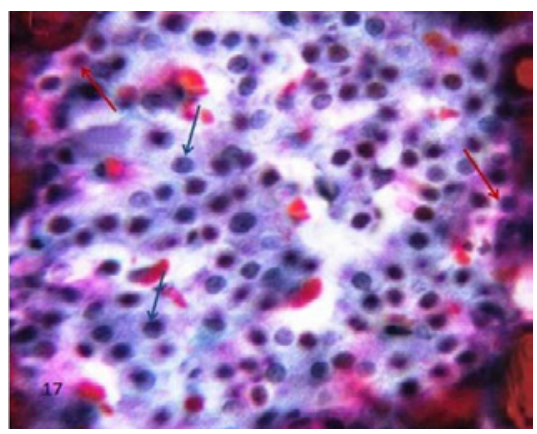

Figure 16: A Photomicrograph of rat pancreatic tissue of the quercetin treated group showing relatively numerous $\beta$-cells (blue arrows), notice $\alpha$ cells at the periphery of islet(red arrows). (chrome alum Hx. X400).

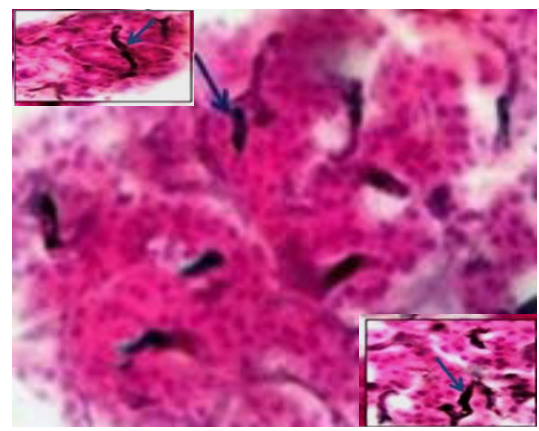

Figure 17: A Photomicrograph of rat pancreatic tissue of the control group showing an islet having charcoal injected blood vessels in between islet's cells (lower inset)and between acini (upper inset) (arrows). (X400).

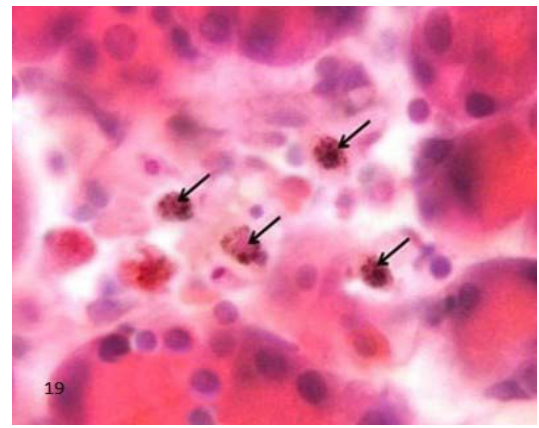

Figure 18: A Photomicrograph of rat pancreatic tissue of the diabetic group showing an islet having charcoal labeled macrophages. "The labeled cells" are large with irregular outline and their cytoplasm displayed yellowish brown charchol granules (arrows). (X 1000).

In the diabetic group (group II), STZ administration caused changes in the expression of iNOS in the pancreatic tissue. Sections of this group displayed positive immunoreactivity in the cytoplasm of some degenerated islet cells and the inflammatory cells infiltrating the islets. Some endothelial cells of the blood vessels and some acinar cells also showed positive immunoreactivity (Figure 21).

In the QCT treated group (group III), there was no immunoreactivity for iNOS in islet and acini but faint expression was still noticed in the endothelium of the blood vessels (Figure22).

Immunohistochemical study of the rat pancreatic tissues using activated (cleaved) Caspase 3: No detectable immunolabeling for activated caspase 3 in the pancreatic sections of the control group (Figure 23).

In the diabetic group (group II), STZ administration caused changes in the expression of active caspase 3 in the rat pancreas. There was obvious high immunoreactivity for activated caspase 3 in the islets. The expression in the islet showed a pattern of heterogeneity; most of the islet's cells had shown both cytoplasmic and nuclear expression while others showed only cytoplasmic expression. Few macrophage like cells showed positive immunoreactivity (Figure 24).

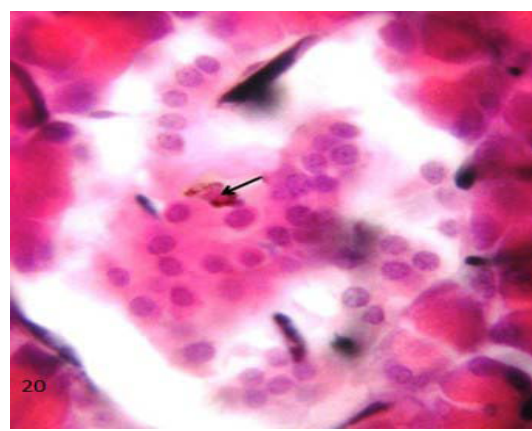

Figure 19: A Photomicrograph of rat pancreatic tissue of the quercetin treated group showing an islet having reduced number of charcoal labeled macrophage (arrow). (X1000).

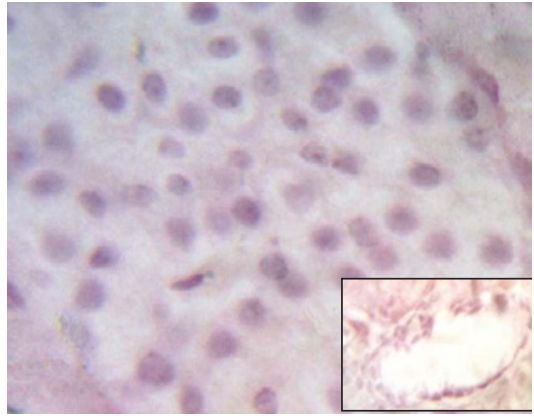

Figure 20: A Photomicrograph of rat pancreatic tissue of the control group immunostained for iNOS showing negative immunoreactivity in the islet cell, the acini and endothelium of blood vessels (inset). (immunohistochemistry counter stain $\mathrm{Hx} \times 1000$ )

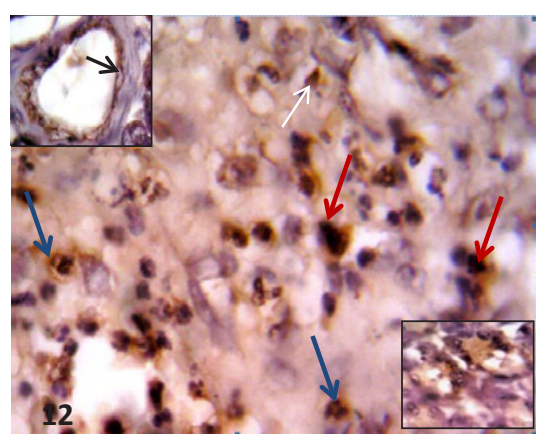

Figure 21: A Photomicrograph of rat pancreatic tissue of the diabetic group immunostained for iNOS showing positive immunoreactivity in the inflammatory cells (blue arrows), and macrophage like cells (red arrows) infiltrating the islet. Positive immunoreactivity seen aslo in the degenerated islet cells (white arrow). Notice positive immunoreactivity in the endothelium of blood vessel (upper inset) and in some acinar cells (lower inset). (x1000) 
Citation: Rifaai RA, El-Tahawy NF, Saber EA, Ahmed R (2012) Effect of Quercetin on the Endocrine Pancreas of the Experimentally Induced Diabetes in Male Albino Rats: A Histological and Immunohistochemical Study. J Diabetes Metab 3:182. doi:10.4172/2155-6156.1000182

Page 7 of 11

In the QCT-treated group (group III), the profile of activated caspase 3 expression in the pancreas was changed after QCT administration when compared to the previous group. There was marked decline in the activated caspase 3 immunolabeling in the islet region (Figure 25).

\section{The morphometric results}

Morphometric analysis of the number of islets per square millimeter: There was a significant decrease in the number of pancreatic islets $/ \mathrm{mm}^{2}$ of the STZ induced diabetic group compared to the control group ( $\mathrm{p}=0.000$ ). On the other hand, there was a significant

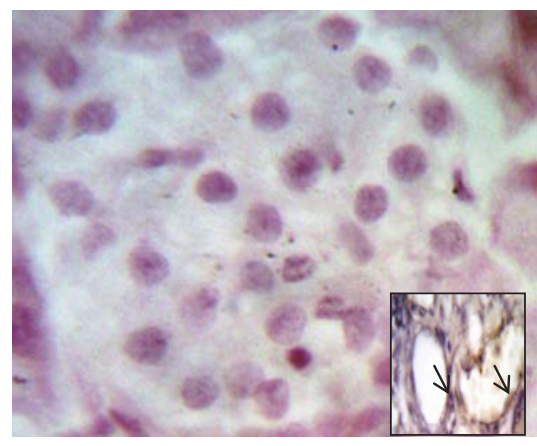

Figure 22: A Photomicrograph of rat pancreatic tissue of the quercetin treated group immunostained for iNOS showing negative immunoreactivity in the islet and the acini. Inset showing faint expression in the endothelium of blood vessel (arrow). (x1000).

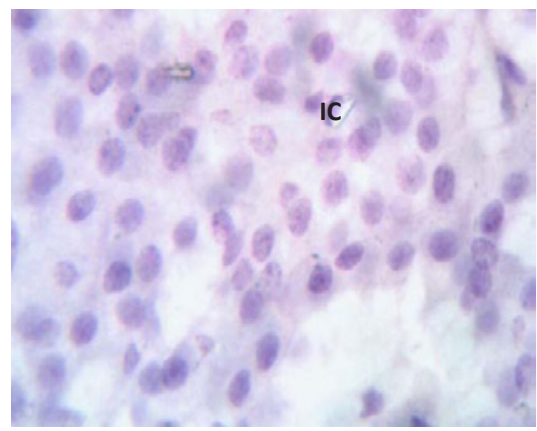

Figure 23: A photomicrograph of pancreatic tissue of the control group for caspase 3 showing negative immuostained immunoreactivity in the islet's cells. (x1000)

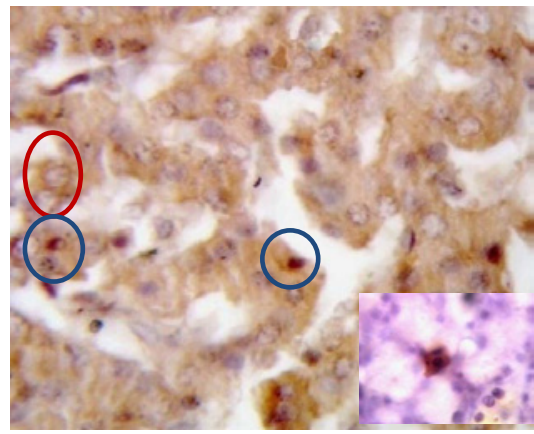

Figure 24: A photomicrograph of pancreatic tissue of the diabetic group immuostained for caspase 3 showing positive immunoreactivity in cytoplasm of some islet cells (red circles). Notice nuclear expression of the other cells (blue circles). Notice positive stained macrophage like cell (inset). (x1000).

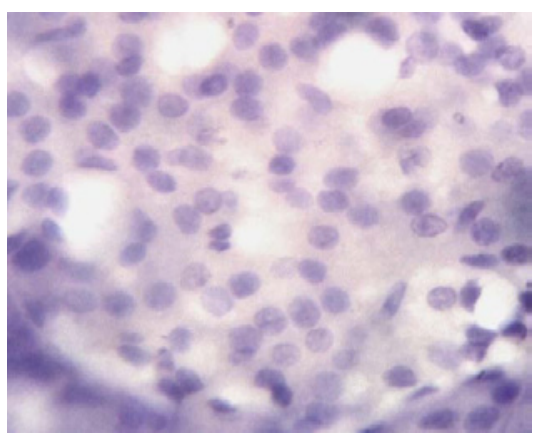

Figure 25: A photomicrograph of pancreatic tissue of the quercetin treated group immuostained for caspase 3 showing faint immunoreactivity in the islet cells (IC). (X1000).

increase in the number of the islets of QCT-treated group compared to the STZ induced diabetic group $(\mathrm{p}=0.000)$. There was no significant difference in the number of the islets in QCT-treated group compared to control group ( $\mathrm{p}=0.258$ ) (Table 2$)$.

Morphometric analysis of the number of $\beta$ cells per islet: There was a significant decrease in the number of B cells in the islet of the STZ induced diabetic group compared to the control group $(\mathrm{p}=0.000)$. On the other hand, there was a significant increase in the number of $\beta$ Cells of QCT-treated group compared to the STZ induced diabetic group $(\mathrm{P}=0.000)$. Meanwhile, there was no significant difference of a number of $\beta$ cells in QCT-treated group compared to the control group $(\mathrm{p}=0.366)$ (Table 3).

Morphometric analysis of the total number of cells in each islet: There was a significant decrease in the total number of cells in each islet of the STZ induced diabetic group compared to the control group $(\mathrm{p}=0.000)$. On the other hand, a significant increase in the total number of cells in each islet of the QCT-treated group compared to the STZ induced diabetic group $(p=0.002)$. There was no significant difference of the total number of cells in QCT-treated group compared to control group $(\mathrm{p}=0.447)$ (Table 4).

Percent of $B$ cells to the total number of cells in each islet: The percent of $\beta$ cells in the control group ranged from $60 \%-75 \%$.There was a decrease in percent of $\beta$ cells (28\%-50\%) after STZ induced diabetes, while in QCT-treated group an increase in the percent of $\beta$ Cells in each islet (50\%-60\%) was observed compared to the STZ induced diabetic group.

\section{Discussion}

In this study a high dose of STZ was used to induce DM1. High dose treatment of STZ induced a more rapid loss of insulin secretion and therefore more rapid onset of diabetes compared to low dose treatment [18]. A dose of $60-75 \mathrm{mg} / \mathrm{kg}$ of STZ causes destruction of islet cells [19]. Destruction of $\beta$-cell in rat's pancreas starts 3 days after STZ administration and reaches its peak at 3-4 weeks [20]. In this study, the blood glucose level of diabetic group had started to increase at $48 \mathrm{~h}$ after injection of STZ $(18.2 \pm 0.3 \mathrm{mmol} / \mathrm{l})$ and reached the highest level at 30 day after injection $(21.3 \pm 0.4 \mathrm{mmol} / \mathrm{l})$ this was in comparison to the control group ( $4.1 \pm 0.4 \mathrm{mmol} / \mathrm{l})$. QCT treatment prior to induction of diabetes was found to have beneficial effect on hyperglycemia, blood glucose level returned to a relatively normal value. This result in agreement with Rivera et al. [21], who found that quercetin has a beneficial effects on blood glucose level in Obese rats which received a daily dose of 2 or $10 \mathrm{mg} / \mathrm{kg}$ of quercetin, orally for 10 weeks. 
Citation: Rifaai RA, El-Tahawy NF, Saber EA, Ahmed R (2012) Effect of Quercetin on the Endocrine Pancreas of the Experimentally Induced Diabetes in Male Albino Rats: A Histological and Immunohistochemical Study. J Diabetes Metab 3:182. doi:10.4172/2155-6156.1000182

\begin{tabular}{|l|l|l|}
\hline & $\mathrm{MN} \pm \mathrm{SD}$ & $\mathrm{p}$-value \\
\hline Control group & $4.1 \pm 0.23$ & \\
\hline Diabetic group & $1 \pm 0.85$ & $0.000^{\mathrm{c}}$ \\
\hline QCT-treated group & $3.3 \pm 0.28$ & $0.258^{\mathrm{c}}$ \\
& & $0.000^{\mathrm{d}}$ \\
\hline
\end{tabular}

$p<0.05$ is significant, "versus control group, ${ }^{d} \mathrm{Q} C T$-treated group versus diabetic group

Table 2: The number of islets $/ \mathrm{mm}^{2}$ in the control and experimental groups.

\begin{tabular}{|l|l|l|}
\hline & $\mathrm{MN} \pm \mathrm{SD}$ & $\mathrm{p}$-value \\
\hline Control group & $86.7 \pm 34.09$ & \\
\hline Diabetic group & $19.66 \pm 6.59$ & $0.000^{\mathrm{c}}$ \\
\hline QCT-treated group & $78.46 \pm 25.21$ & $0.366^{\mathrm{c}}$ \\
$0.000^{\mathrm{d}}$
\end{tabular}

$p<0.05$ is significant, c versus control group, ${ }^{d} Q C T$-treated group versus diabetic group

Table 3: The number of $\beta$ cells per islet in the control and experimental groups.

\begin{tabular}{|l|l|l|}
\hline & $\mathrm{MN} \pm \mathrm{SD}$ & $\mathrm{p}$-value \\
\hline Control group & $17.06 \pm 43.96$ & \\
\hline Diabetic group & $60.53 \pm 22.55$ & $0.000^{\mathrm{c}}$ \\
\hline QCT-treated group & $06.20 \pm 44.95$ & $0.447^{\mathrm{c}}$ \\
$0.002^{\mathrm{d}}$
\end{tabular}

$p<0.05$ is significant, $c$ versus control group, ${ }^{d} Q C T$-treated group versus diabetic group

Table 4: The total number of all cells of islet in the control and experimental groups.

In this study the histological observations using H\&E stain showed that the pancreatic islets from control group displayed normal histological features. In the diabetic group, marked morphological changes were observed including breakdown of microanatomical features, marked inflammatory cells infiltration. The islets showed marked degeneration of their cells. These degenerated cells appeared with nuclear pyknosis, fragmentation, and others showed cytoplasmic vacuolation. Cellular residues were seen within the cytoplasm of phagocytic cells. Phagocytic cells cleaning resulted in empty spaces. In some sections the empty spaces leaved after cell degeneration was seen to be filled with amyloid like material. In few animals, the islets were completely destroyed leaving empty spaces which were previously occupied by islet cells. The present study reinforced the previous recorded result which mentioned that diabetes caused extensive $\beta$-cell degranulation and decreased cellular density in pancreatic islets [2]. Selective destruction of insulin producing $\beta$ cells could be explained by Blair et al. [22], who reported that DM1 is characterized by inflammatory reaction in and around the islets followed by $\beta$ cell degeneration. Inflammatory reaction is caused by inflammatory cells, these cells being the humoral mediators of immunologic process and release of various cytokines. Cytokines are immunological effector molecules responsible for inhibition of insulin secretion from pancreatic $\beta$ cells and inducing $\beta$ cell destruction [23]. Amyloid; an insoluble fibrous protein, studies have shown that the amyloid deposition is associated with mitochondrial dysfunction and lead to the generation of reactive oxygen species (ROS) which can initiate a signaling pathway leading to apoptosis [24].

In the present work, histological finding of the pancreas of QCTtreated group showed that QCT administration improved the previous degenerative changes in most of the rats. Many islets were showed with increased cells along with a reduction in the inflammatory cells infiltration. This was in agreement with Adewole et al. [2], who found that in diabetic rats treated with QCT, there were no evidence of inflammatory cells infiltration and the islets were observed with increase in granulation intensity.
There was an interesting finding in this work which was the presence of cellular connections between some ducts and the islets cells, this might be explained by Xiu et al. [25], who reported that islet stem cells or progenitor cells exist in the adult pancreas are located in or near the pancreatic duct. Some stimuli can trigger these stem cells to differentiate into endocrine cells. The reverse of diabetes in diabetic animals was due to formation of new islets from ductal cells [26]. From these facts it could be suggested that QCT may trigger duct stem cell to differentiate into endocrine cells which were confirmed by morphological and morphometric results in this study. This study may add a new mechanism of the protective role of QCT against diabetes. So the newly generated islets may have formed from the ductal precursor cells.

Histological finding of the pancreatic tissue using chrome alum heamatoxylin of the control group showed bluish stained $\beta$ cells filling the interior of the islet, while pink stained $\alpha$-cells are arranged in clusters scattered mainly at the periphery of the islets and also between $\beta$ cells. Morphological and morphometrical study of the diabetic group, degenerative changes were seen especially at the center of islets with decrease number of the bluish stained $\beta$ cells while the pink stained alpha cells still present at the periphery of the islet, the injection of STZ caused a significant decrease in the number of pancreatic islets $/ \mathrm{mm}^{2}$ and the number of $\beta$ cells in the islet as compared to control group. This was in agreement with Al-Khalifa et al. [27], who reported that a significant decrease in the number of $\beta$ cells in all diabetic groups as compared with the respective control groups. In QCT-treated group, morphmetric results showed that there was a significant increase in the number of the islets $/ \mathrm{mm}^{2}$ and the number of $\beta$ cells in islet compared to diabetic group. There was no significant difference in the number of islets $/ \mathrm{mm}^{2}$ compared to the control group. There was a significant decrease in percent of $\beta$ cells $(28 \%-50 \%)$ in diabetic group, while in QCT-treated group a significant increase in percent of $\beta$ Cells in each islet (50\%-60\%) compared to the diabetic groups. The QCT may act on islet functions, increasing the number of pancreatic islets and stimulating insulin release in diabetic rats [28].

For further assessment of the protective role of QCT on diabetes and its mechanisms for the protection, histological study of the pancreatic macrophages using charcoal and immunohistochemical study of rat pancreatic tissues using iNOS and caspase 3 were done.

Intravenous injection of charcoal has been shown to provide a method for visualizing the phagocytes. In this work, macrophages in sections of diabetic group appeared more frequently and widely distributed when compared to the control group. The labeled cells were large with irregular outline. Their cytoplasm displayed yellowish brown charchol granules. Macrophages were present in many pancreatic islets during insulitis. In approval with speculations of the role of macrophages in the pathogenesis of DM1, macrophages are present in islets and in experimental conditions macrophages are able to engulf insulin granules from damaged $\beta$ cells [29]. Islet cytokines and other inflammatory mediators elicit activation of vascular endothelium [30]. Endothelial activation in the pancreas leads to increased adhesion, extravasations of circulating leukocytes and presentation of target antigens by infiltrated macrophages and perhaps by endothelial cells themselves. The activated T-cells first invade the islets leading to insulitis. This is followed by destruction of the islets, mediated by a complex interaction between the activated lymphocytes, cytokines, and macrophages. Cytokines produced by islet infiltrating macrophages may contribute to $\beta$ cell damage by inducing the production of oxygen free radicals in the islets. These cytokines, which are released from 
activated macrophages, are believed to be toxic to $\beta$ cells [31]. The toxic effect produced by activated macrophages on $\beta$ cells is thought to be mediated by the superoxide anion and hydrogen peroxide and $\beta$ cell is very sensitive to the production of free radicals because islet cells exhibit very low free radical scavenging activity [32]. In QCT-treated group in this study, the charcoal labeled macrohages were markedly decreased all over the pancreatic sections, especially in the islet region compared to the diabetic group suggested that QCT had a protective role as anti-inflammatory in decreasing the mediators of inflammation in diabetes. This finding was in the same line of Overman et al. [33], who reported that QCT reduced the inflammation in human and prevent the mediator of this inflammation.

It is also believed that possible mediator of pancreatic $\beta$ cell damage is radical NO and iNOS is the most involved of NOS isoforms in immune mediated $\beta$ cell damage. High level of NO produced by iNOS is related to pancreatic $\beta$ cell dysfunction and apoptosis [34]. A significant increase of NO synthesized by iNOS participates in provoking inflammatory process and acts synergistically with other inflammatory mediators and compounds able to reduce NO production by iNOS may be attractive as anti-inflammatory agents [35]. In this study iNOS might play a role in the protective effect noticed after QCT treatment in diabetes, so this study analyzed iNOS expression in the pancreatic tissue under diabetic conditions as well as it was examined upon treatment with QCT. Immunocytochemical study using iNOS showed that in the control group negative iNOS immunoreactivity was noticed in either the islets cells, acinar cells or the blood vessels. This in agreement with Liu et al. [36], who reported that NO produced under physiological conditions contributes to cellular functions in pancreatic beta-cells just like in other cells, but it is not determined which type nitric oxide synthase isoform produces $\mathrm{NO}$ under physiological conditions, presence of iNOS in pancreas and islets under physiological conditions has not been exactly elucidated. In this study, the diabetic group showed positive iNOS immunoreactivity in the inflammatory cells infiltrating the islets, the endothelium of blood vessels and in some acinar cells. There was an intense immunostaining for iNOS in STZ induced diabetic rat as compared with the control rats. This enhanced iNOS levels induced by STZ suggests the oxidative stress which may led to the degeneration of $\beta$ cells of the pancreas. The previous results were in agreement with Johannesen et al. [37], who reported that there is a high level of iNOS expression in the diabetic animals but he suggested that NO is necessary but not sufficient by itself in cytokine mediated selective $\beta$ cell destruction. NO production in $\beta$ cells, macrophages, ductal cells, and endothelial cells has been considered [38]. Ductal cells are potential source of NO production in human islets which have been infiltrated by cytokine releasing immunocytes [39]. The present data indicate that the possible contribution of $\beta$ cell iNOS is restricted to the close vicinity of macrophages. The other possible site of iNOS expression is the endothelium. In fact several studies have shown that endothelial cells respond to cytokine challenge with sustained NO release [40]. This indicates that macrophages themselves express iNOS. In addition, macrophages may have induced adjacent endothelial or endocrine islet cells by inflammatory mediators to secrete NO, Such mediators are IL-l and TNF [41]. The expression of iNOS in islet $\beta$ cells is mediated by the cytokines interleukin-1 $\beta$ (IL-1 $1 \beta$ ), tumor necrosis factor- $\alpha$ (TNF- $\alpha$ ), and interferon- $\gamma$ (IFN $\gamma$ ), produced by lymphocytes and macrophages that are known to infiltrate the islets during the development of DM1. It was reported that endogenous $\mathrm{NO}$ is involved in formation of pancreatic edema by increasing the vascular permeability and protein extravasation. NO, participate in the development of pancreatic microcirculatory failure $[23,42]$. This study showed that in the QCT-treated group there was negative iNOS immunoreactivity in the islet and acini with faint expression noticed in the endothelium of some blood vessels. This finding suggesting the ability of QCT to function as an antioxidant against nitrosative stress. This was in the same line with the study of Kleemann et al. [43], who has been shown that the pharmacological inhibition of iNOS protects against $\beta$ cell damage and reduces the sensitivity of animals against induction of diabetes. Polyphenols inhibit NO release by suppressing NOS enzymes expression and/or NOS activity [44]. Flavonoids appeared to be a potential therapeutic agent against DM1, and QCT has been shown to exert protective effect on $\beta$ cells by different mechanisms including blocking iNOS gene expression. Caspases play a key role in apoptosis [45]. Immunohistochemical localization of activated (cleaved) caspase 3 in rat pancreatic tissues as an indicator of apoptosis was performed. In this study no detectable immunolabeling for activated caspase 3 in the pancreatic sections of the control group but in diabetic group there was high expression of active caspase 3 . There was obvious high immunoreactivity for activated caspase 3 in the islets. The expression in the islet showed a pattern of heterogeneity i.e. most of the islet cells had shown both cytoplasmic and nuclear expression while others showed only cytoplasmic immunoreactivity. Few macrophage like cells showed positive immunoreactivity. STZ induced pancreatic $\beta$-cell death is associated with oxidative stress caused by the production of excess intracellular ROS furthermore, STZ may damage pancreatic tissue via imposition of oxidative as well as nitrosative stresses, which in turn can induce apoptosis in pancreatic cells with an invasion of the islets by macrophages and $\mathrm{T}$ cells termed insulitis. These activated inflammatory cells produce cytokines, such as IL- $1 \beta$, IFN $\gamma$, and TNF- $\alpha$, which cause progressive destruction of most $\beta$-cells via apoptosis, leading to an absolute deficiency of insulin [46]. Based on animal studies, it is assumed that decreased beta cell mass in DM1 is due to increased beta cell apoptosis [47]. Beta cells are also vulnerable to apoptosis when exposed to glucose concentrations of approximately $11 \mathrm{mmol} / \mathrm{l}(200 \mathrm{mg} / \mathrm{dl})$ or higher through mechanisms that include $\beta$ cell expression and the action of IL-1 [48]. In contrast to this study, Reddy et al. [49], reported that caspase-3 immunoreactivity predominantly intra islet macrophages but not islet cells, suggesting that apoptotic $\beta$ cells are cleared rapidly after onset of diabetes. The discrepancy between the present results and theirs might be due to the different stages of insulinitis to which islets cells responded. In the QCT treated group, there was marked decline in the activated caspase 3 immunolabeling in the islet region. This can be explained by Ardestani and Yazdanparast [50], who reported that the activation of NF- $\kappa$ B by acute oxidative stress may be the critical signal initiating the cascade of events leading to $\beta$-cell death and DM1. Thus, understanding these ROS-induced signal pathways in the immune and inflammatory response becomes essential in finding preventive treatments. Therapy that can target the activation of NF- $\kappa \mathrm{B}$ may be an effective therapeutic tool in finding treatments to cure DM1. In view of their antiinflammatory and antioxidant abilities and their capacity to modulate NF- $\mathrm{kB}$ signaling pathways which lead to apoptosis, it is hypothesized that flavonoids as QCT hold great promise as potential therapeutic agents for controlling the onset of DM1.

In conclusion, the morphological and morphometrical findings suggested that the administration of QCT to diabetic rats causes beneficial effect in terms of regeneration of $\beta$ cells in damaged pancreas. Hence it is concluded that QCT possess preventive and curative effect on STZ induced diabetes in rats, so it can be used as a herbal medicine to protect the pancreatic $\beta$ cells. This protective effect may be through its inhibitory effect on iNOS levels and apoptosis. QCT may have a 
Citation: Rifaai RA, El-Tahawy NF, Saber EA, Ahmed R (2012) Effect of Quercetin on the Endocrine Pancreas of the Experimentally Induced Diabetes in Male Albino Rats: A Histological and Immunohistochemical Study. J Diabetes Metab 3:182. doi:10.4172/2155-6156.1000182

stimulatory effect on ductal stem cells to differentiate and regenerate islet cells.

\section{References}

1. Savage DB, Petersen KF, Shulman GI (2007) Disordered lipid metabolism and the pathogenesis of insulin resistance. Physiol Rev 87: 507-520.

2. Adewole SO, Caxton-Martins EA, Ojewole JA (2006) Protective effect of quercetin on the morphology of pancreatic $\beta$-cells of streptozotocin-treated diabetic rats. Afr J Tradit Complement Altern Med 4: 64-74.

3. Revilla-Monsalve MC, Andrade-Cetto A, Palomino-Garibay MA, Wiedenfeld $\mathrm{H}$, Islas-Andrade S (2007) Hypoglycemic effect of Cecropia obtusifolia Bertol aqueous extracts on type 2 diabetic patients. J Ethnopharmacol 111: 636-640.

4. Schoenfelder T, Cirimbelli TM, Citadini-Zanette V (2006) Acute effect of Trema micrantha (Ulmaceae) on serum glucose levels in normal and diabetic rats. $J$ Ethnopharmacol 107: 456-459.

5. Merzouk H, Madani S, Chabane Sari D, Prost J, Bouchenak M, et al. (2000) Time course of changes in serum glucose, insulin, lipids and tissue lipase activities in macrosomic offspring of rats with streptozotocin-induced diabetes. Clin Sci (Lond) 98: 21-30.

6. Coskun O, Kanter M, Korkmaz A, Oter S (2005) Quercetin, a flavonoid antioxidant, prevents and protects streptozotocin induced oxidative stress and $\beta$-cell damage in rat pancreas. Pharmacol Res 51: 117-123.

7. Elsner M, Guldbakke B, Tiedge M, Munday R, Lenzen S (2000) Relative importance of transport and alkylation for pancreatic beta-cell toxicity of streptozotocin. Diabetolgia 43: 1528-1533.

8. Bogle RG, Moncada S, Pearson JD, Mann GE (1992) Identification of inhibitors of nitric oxide synthase that do not interact with the endothelial cell L-arginine transporter. Br J Pharmacol 105: 768-770.

9. Qader SS, Ekelund M, Andersson R, Obermuller S, Salehi A (2003) Acute pancreatitis, expression of inducible nitric oxide synthase and defective insulin secretion. Cell Tissue Res 313: 271-279.

10. Kim JD, Kang SM, Park MY, Jung TY, Cho HY, et al. (2007) Ameliorative antidiabetic activity of dangnyosoko, Chinese herbal medicine in diabetic rats. Biosci Biotechnol Biochem 71: 1527-1534.

11. Zhang S, Qin C, Safe SH (2003) Flavonoids as aryl hydrocarbon receptor agonists/antagonists: effects of structure and cell context. Environ Health Perspect 111: 1877-1882.

12. Abd El-Baky AE (2011) Quercetin protective action on oxidative stress, sorbitol, insulin risistance and cells function in expermintal diabetic rat. International Journal of Pharmaceutical Studies and Research 2: 2229-4619.

13. Rossini AA, Williams RM, Appel MC, Like AA (1978) Complete protection from low-dose streptozotocin-induced diabetes in mice. Nature 276: 182-184.

14. Saber EA (2002) Switching in the sites of haemopoiesis in the spleen and bone marrow of mice during late prenatal and early postnatal life and the role of scavenger macrophages. Egypt J Anat 25: 55-89.

15. Kanter M, Meral I, Yener Z, Ozbek H, Demir H (2003) Partial regeneration/ proliferation of bcells in the islets of langerhans by Nigilla Sativa Linn in streptozotocin induced diabetics rats .Tohoku J Exp Med 201: 213-219.

16. Carleton HM, Drury RAB, Wallington EA (1980) Carlton's histological technique (5thedn), New York: Oxford University Press 173-174.

17. Côté A, da Silva R, Cuello AC (1993) Current protocols for light microscopy immunocytochemistry. In: Cuello AC, editor. Immunohistochemistry II: John Wiley \& Sons, Chichester 147-168.

18. Howarth FC, Jacobson M, Naseer O, Adeghate E (2005) Short-term effects of streptozotocin-induced diabetes on the electrocardiogram, physical activity and body temperature in rats. Exp Physiol 90: 237-245.

19. Akbarzadeh A, Norouzian D, Mehrabi MR, Jamshidi Sh, Farhangi A, et al. (2007) Induction of diabetes by streptozotocin in rats. Ind J Clin Biochem 22 60-64.

20. Adeghate E, Ponery AS (2002) Ghrelin Stimulates Insulin Secretion from the Pancreas of Normal and Diabetic Rat. J Neuroendocrinol 14: 555-560.

21. Rivera L, Moron R, Sanchez M, Zarzuelo A, Galisteo M (2008) Quercetin ameliorates metabolic syndrome and improves the inflammatory status in obese Zucker rats. Obesity 16: 2081-2017.
22. Blair LA, Maggi LB Jr, Scarim AL, Corbett JA (2002) Role of interferon regulatory factor-1 in double-stranded RNA-induced iNOS expression by mouse islets. J Biol Chem 277: 359-365

23. McDaniel ML, Kwon G, Hill JR, Marshall CA, Corbett JA (1996) Cytokines and nitric oxide in islet inflammation and diabetes. Proc Soc Exp Biol Med 211 24-32.

24. Kadowaki H, Nishitoh H, Urano F, Sadamitsu C, Matsuzawa A, et al. (2005) Amyloid beta induces neuronal cell death through ROS-mediated ASK1 activation. Cell Death Differ 12: 19-24.

25. Xiu LM, Miura AB, Yamamoto K, Kobayashi T, Song QH, et al. (2001) Pancreatic islet regeneration by ephedrine in mice with streptozotocin-induced diabetes. Am J Chin Med 29: 493-500.

26. Banerjee M, Bhonde RR (2003) Islet generation from intra islet precursor cells of diabetic pancreas: in vitro studies depicting in vivo differentiation. JOP 4 : 137-145.

27. Al-Khalifa A, Mathew TC, Al-Zaid NS, Mathew E, Dashti HM (2009) Therapeutic role of low-carbohydrate ketogenic diet in diabetes. Nutrition 25: 1177-1185.

28. Vessal M, Hemmati M, Vasei M (2003) Antidiabetic effects of quercetin in streptozocin-induced diabetic rats. Comp Biochem Physiol C Toxicol Pharmacol 135: 357-364.

29. Hutchings D L, van Drunen Littel-van den Hurk S, Babiuk LA (1990) Lymphocyte proliferative responses to separated bovine herpesvirus 1 proteins in immune cattle. J Virol 64: 5114-5122.

30. Pober JS, Cotran RS (1990) Cytokines and endothelial cell biology. Physio Rev 70: 427-451.

31. Pankewycz OG, Guan JX, Benedict JF (1995) Cytokines as mediators of autoimmune diabetes and diabetic complications. Endocr Rev 16: 164-176.

32. Faust A, Kleemann R, Rothe H, Kolb H (1996) Role of macrophages and cytokines in b-cell death. In Shafrir E (Ed) Lessons from Animal Diabetes VI. Birkhäuser, Cambridge, Massachusetts: 47-56.

33. Overman A, Chuang CC, McIntosh M (2011) Quercetin attenuates inflammation in human macrophages and adipocytes exposed to macrophage-conditioned media. Int J Obes (Lond) 35: 1165-1172.

34. Eizirik DL, Flodstrom M, Karlsen AE, Welsh N (1996) The harmony of the spheres: inducible nitric oxide synthase and related genes in pancreatic beta cells. Diabetologia 39: 875- 890.

35. Nathan C (1992) Nitric oxide as a secretory product of mammalian cells FASEB J 6: 3051-3064.

36. Liu JL, Du J, Fan LL, Liu XY, Gu L, et al. (2008) Effects of quercetin on hyperproliferation of gastric mucosal cells in rats treated with chronic oral ethano through the reactive oxygen speciesnitric oxide pathway. World J Gastroentero 14: 3242-3248.

37. Johannesen J, Pociot F, Karlsen AE, Mandrup-Poulsen T, Nerup J (2001) Strain-dependent difference in inducible nitric oxide synthesis (iNOS) expression in rat pancreatic islets correlates with interferon regulating factor 1 (IRF-1) and heat shock protein 70 (HSP70) expression. Eur Cytokine Netw 12: 501-509.

38. Thomas HE, Darwiche R, Corbett JA, Kay TW (2002) Interleukin-1 plus gamma-interferon-induced pancreatic beta-cell dysfunction is mediated by beta-cell nitric oxide production. Diabetes 51: 311-316.

39. Pavlovic D, Chen MC, Bouwens L, Eizirik DL, Pipeleers D (1999) Contribution of ductal cells to cytokine responses by human pancreatic islets. Diabetes 48 : 29-33.

40. Rothe H, Fehsel K, Kolb H (1990) Tumour necrosis factor alpha production is upregulated in diabetes prone BB rats. Diabetologia 33: 573-575.

41. Jiang Z, Woda BA (1991) Cytokine gene expression in the islets of the diabetic biobreeding/Worcester rat. J Immunol 146: 2990-2994.

42. Takacs T, Czako L, Morschl E, Laszlo F, Tiszlavicz L, et al. (2002) The role of nitric oxide in edema formation in L-arginine-induced acute pancreatitis. Pancreas 25: 277-282.

43. Kleemann R, Rothe H, Kolb-Bachofen V, Xie QW, Nathan C, et al. (1993) Transcription and translation of inducible nitric oxide synthase in the pancreas of prediabetic BB rats. FEBS Lett 328: 9-12. 
Citation: Rifaai RA, El-Tahawy NF, Saber EA, Ahmed R (2012) Effect of Quercetin on the Endocrine Pancreas of the Experimentally Induced Diabetes in Male Albino Rats: A Histological and Immunohistochemical Study. J Diabetes Metab 3:182. doi:10.4172/2155-6156.1000182

44. Kim HP, Son KH, Chang HW, Kang SS (2004) Anti-inflammatory plant flavonoids and cellular action mechanisms. J Pharmacol Sci 96: 229-245.

45. Shi Y (2004) Caspase activation: revisiting the induced proximity model. Cell 117: 855-858

46. Han SH, Jeon JH, Ju HR, Jung U, Kim KY, et al. (2003) VDUP1 upregulated by TGF-beta1 and 1,25-dihydorxyvitamin D3 inhibits tumor cell growth by blocking cell-cycle progression. Oncogene 22: 4035-4046.

47. Jorns A, Kubat B, Tiedge M, Wedekind D, Hedrich HJ, et al. (2004) Pathology of the pancreas and other organs in the diabetic LEW.1AR1/Ztm-iddm rat, a new model of spontaneous insulin-dependent diabetes mellitus. Virchows Arch 444: 183-189.
48. Maedler K, Sergeev P, Ris F, Oberholzer J, Joller-Jemelka HI, et al. (2002) Glucose-induced beta cell production of IL-1 beta contributes to glucotoxicity in human pancreatic islets. J Clin Invest 110: 851-860.

49. Reddy S, Bradley J, Ginn S, Pathipati P, Ross JM (2003) Immunohistochemical study of caspase-3-expressing cells within the pancreas of non-obese diabetic mice during cyclophosphamide-accelerated diabetes. Histochem Cell Biol 119 451-461.

50. Ardestani A, Yazdanparast $R$ (2007) Down regulation of NF-kappa B as a therapeutic strategy for type 1 diabetes: effect of flavonoids. Irn J Med Hypotheses Ideas 1: 8. 